\title{
Det finsk-svenska symposiet om modern strafflagstiftning
}

\author{
Av professor, jur. dr. RAIMO LAHTI, Åbo
}

Turun Yliopistosäätiö, en stiftelse som understöder verksamheten vid Åbo universitet (Turun yliopisto), gjorde det genom anslag möjligt för straff- och processrättsliga avdelningen vid Institutionen för offentlig rätt vid samma universitet att anordna ett finsk-svenskt symposium kring frågor om modern strafflagstiftning. Symposiet ägde rum 29-30 augusti 1977 i Åbo Akademis Studentkårs konferensutrymmen och samlade ungefär trettio deltagare.

Till den grupp som planerare symposiet hörde förutom lärarna i straffrätt vid Åbo universitet professorerna Inkeri Anttila, Alvar Nelson och Pekka Koskinen. Symposiet hade delvis en fortbildningsfunktion och ingick därför i schemat för undervisningen vid Juridiska fakulteten. - I detta sammanhang kan omnämnas, att den förordning som gäller juridiska studier (Förf.saml. 802/74) även ställer krav på att man utvecklar formerna för fortbildning. Denna förordning trädde i kraft 1 augusti 1977. - Såsom eftersträvansvärt ansågs, att symposiet skulle påverka umgänget och utbytet av kunskap de nordiska forskarna emellan i positiv riktning. Tyvärr blev man p. g. a. de knappa ekonomiska resurserna tvungen att kraftigt begränsa antalet inbjudna. De flesta deltagarna fungerar vid Åbo, Helsingfors eller Uppsala universitet.

Det enhetliga temat för hela symposiet var modern strafflagstiftning. Med detta ville man säga, att de utvalda ämnena är viktiga isynnerhet då det är fråga om nutida strafflagstiftning eller moderniserandet (förnyandet) av strafflagstiftningen. Det var inte meningen att begränsa granskningen till enbart rättspolitiska synpunkter. De rättsdogmatiska problemställningarna är dessutom av stor betydelse, när man förnyar lagstiftning.

I symposiets program ingick tre skilda teman: (I) culpösa brott, (II) straffrättsligt ansvar i samfund och (III) den finska straffrättskommitténs kriminaliseringsförslag. Vart och ett av dessa ämnen inleddes av en referent och en korreferent. Därefter beredde man deltagarna tillfälle till diskussion.

Förnyandet av strafflagstiftningen har varit högst aktuellt i Finland. I början av 1977 utkom straffrättskommitténs betänkande, som varit under bearbetning i närmare fem år (Rikosoikeuskomitean mietintö. Komiteanmietintö-Kommittébetänkande 1976:72. Helsinki-Helsingfors 1976). Vid tidpunkten för symposiet cirkulerade betänkandet hos olika myndigheter och organisationer för givande av utlåtanden. 
Betänkandets aktualitet påverkade i hög grad valet av teman för symposiet. Av de tre ämnen som togs upp på symposiets program angick det tredje uttryckligen kommittébetänkandet. Därvid koncentrerade man sig, med utgång från Patrik Törnudds (kommitténs medlem och sekreterare) referat, på kommitténs förslag till kriminaliseringar. Kommittén ansåg, att huvudmotivet för en totalreform av straffrätten ,är behovet att på ett konsekvent sätt granska och bedöma de värden som skall skyddas och som skall straffas“. Därför bör enligt kommittén en förnyelse av straffstadgandena komma i första hand i totalreformen.

Även symposiets andra ämne, straffrättsligt ansvar i samfund, hade nära anknytning till straffrättskommitténs betänkande. Kommittén föreslog, visserligen under stora meningsskiljaktigheter, ett införande av straffrättsligt ansvar för samfund. P. O. Träskman granskar kritiskt i sitt referat straffrättskommitténs och vissa andra offentliga utredningars förslag om införande av ett korporativt straffansvar.

Symposiets första ämne, culpösa brott, är ett av de teman som ingår i programmet för den tolfte internationella straffrättskongressen 1979 i Hamburg. Nils Jareborgs skriftliga referat bestod av hans rapport till denna kongress: det anförande som publiceras här är en modifierad version av rapporten. Med anknytning till symposiets allmänna tema kan man konstatera, att kongressens rapportörer uppmanades att dryfta bl. a. samhällets moderniseringsprocessers, $d$. v. s. den vetenskapliga och tekniska revolutionens, förhållande till regleringen av det straffrättsliga ansvaret p. g. a. culpösa brott. Detta tema är icke heller utan intresse för straffrättskommitténs del. I sitt korreferat behandlar Pekka Koskinen problem rörande de culpösa brotten i belysning av kommitténs ställningstaganden.

Genom att i samarbete med redaktionen för Nordisk Tidsskrift for Kriminalvidenskab publicera inledningsanförandena och diskussionsinlägg önskas, att detta material skall inspirera till resonemang inom vidare kretsar än den som kunde delta i symposiet.

Raimo Lahti 